\title{
The Black Culture Movement and the Black Community
}

\author{
by JOHN RUNCIE \\ University of Leicester
}

The problem of defining a coherent cultural identity is one that has confronted generations of Afro-Americans. As part of the justification and defence of slavery and the slave trade many whites rationalized their actions by arguing that all Africans were cultureless savages. The same combination of guilt and arrogance induced them to attempt to suppress and denigrate surviving elements of a culture whose very existence they had already denied. Most black Americans responded to these pressures by rejecting Africa and their African heritage as a source of shame and by trying to deny and to erase their blackness. Malcom X clearly understood this when he proclaimed in 1965 : 'We have been a people who hated our African characteristics. We hated our black heads, we hated the shape of our noses..., we hated the color of our skin.' ${ }^{1}$ Identification with the dominant white culture took many forms. For some Blacks it involved the use of hair straightening and skin bleaching; for others it meant the elimination of any ethnic quality in their speech, dress, cuisine and religion; for many more it meant a life of morality and hard work lived according to the dictates of the Puritan ethic. The loss of any distinctive cultural identity involved in this process was made worse by the unwillingness of white society to recognize and accept the Afro-American as part of the dominant culture. In these circumstances many blacks found themselves in a cultural limbo without an adequate self-image. White domination of the media meant that they sometimes felt literally invisible. James Baldwin drew attention to this dilemma in a speech delivered in June 1963 , when he noted that:

A black child born in this country ... discovers two terrifying things. First of all he discovers that he does not exist in it, no matter where he looks - by which I mean books, magazines, movies - there is no reflection of himself anywhere...

1 Cited in Robert G. Weisbord, Ebony Kinship..Africa, Africans and the Afro-American (Westport, Conn., 1973), p. 182. 
[if] he finds anything which looks like him, he is authoritatively assured that this is a savage, or a comedian who has never contributed anything to civilization. ${ }^{2}$

Given this tendency of white America to ignore the Negro completely or to perceive him only via certain degrading stereotypes, it is hardly surprising that psychiatrists and psychologists frequently found young black children manifesting a marked preference for white dolls and white friends. In this and other ways they rejected their colour and attempted to identify themselves as white. ${ }^{3}$

In the mid-rg6os realization that the Civil Rights movement offered no effective solution to identity crises of this kind, or to the whole problem of cultural marginality, led an increasing number of aware Afro-Americans to the more radical alternative of Black Power. One of the weaknesses of the Civil Rights movement was that it offered no cultural programme other than the integration of Blacks into the dominant white culture, and the implications of this type of 'integration' were greater than a growing number of those Blacks were prepared to accept. Ron Karenga expressed this dissatisfaction when he dismissed integration as a system whereby the white man was prepared to make certain concessions to Blacks "if we could somehow miraculously act, speak, think, smell, look, live and lie to ourselves exactly the way he wanted us to'." This was the crux of the problem. The achievements of the Civil Rights movement encouraged a certain amount of self-esteem and group pride among Afro-Americans, but these trends were inconsistent with the basic assumptions of the integrationist philosophy. For an increasing number of disillusioned Blacks integration implied only the superiority of everything white and the inferiority of everything black. It was a one-way process in which Blacks sought access to white schools, white residential areas, white institutions, white culture and white values, and in doing so denied their own racial identity and their African heritage. The most outspoken critics of the Civil Rights movement went so far as to condemn integration as ' a subterfuge for the maintenance of white supremacy'. They dismissed it as a form of genocide which destroyed black institutions, denied the existence of a separate black culture and effectively absorbed the qualified black élite, while it did nothing for the community as a whole. ${ }^{5}$

As the black protest movement changed direction during the mid-rg6os

2 Cited in Harlem Youth Opportunities Unlimited Inc., Youth in the Ghetto (Ncw York, rí64), pp. 503-4.

3 Alvin Poussaint, 'The Negro American, His Self-Image and Integration', in Floyd B. Barbour, ed., The Black Power Revolt (Boston, 1968), p. 97.

4 Ron Karenga, 'A Strategy for Struggle', Black Scholar, 5 (November 1973), ro-1r.

5 Stokely Carmichael, 'Power and Racism', in Barbour, op. cit., p. 65. See also Robert S. Browne, 'The Case for Two Americas ', New York Times, II August, 1968, vi, pp. 12-13, 50-1. 
and the militant advocates of Black Power gained the ascendancy, it was inevitable that many of them would reject the assumptions of the integrationist philosophy. Instead they emphasized the distinctiveness of black culture, the virtues of black life-styles, and the value of black consciousness and race pride. This celebration of black culture was seen as a form of identity therapy which would liberate the Negro psychologically, erase the negative self-image so prevalent in the black community, and encourage racial solidarity as a necessary basis for the exercise of black political and economic power. Viewed from this perspective black consciousness and Black Power were inseparable and cultural considerations played an important role in the Black Power movement. ${ }^{6}$

The cultural renaissance which flourished among black Americans during the late I960s was a complex and many-dimensioned phenomenon. In its totality it constituted a unique new development in Afro-American history, but there were aspects of the movement which drew on past experience. For example, analogies can be drawn with the Garvey movement which won so much support in the black community after the First World War. Marcus Garvey preached a powerful doctrine of black pride, racial solidarity and African nationalism. He exalted the strength, beauty and superiority of blackness and emphasized the culture and history of Africa as an additional source of pride for the American Negro.

The Ig2os was also a period of cultural ferment among black poets, writers and artists. In certain respects the Harlem Renaissance anticipated the activities of black intellectuals in recent years, but the parallel is far from exact and the differences were often as great as the similarities. One major distinction lay in the high level of white involvement in the twenties movement. White intellectuals were indispensable because of their patronage and their influence with publishers and critics. In his recent study of the Harlem Renaissance, Nathan Huggins suggests that ' in a sense it was as much a white creation as it was black '. In addition the Renaissance tended to be much more élitist, much less broadly based, and it was governed by aesthetic considerations very different from those which prevail among today's more committed black artists. There was something uncomfortably self-conscious about Countee Cullen's aspiration ' to be a poet, not a Negro poet ', ${ }^{8}$ and about his efforts to inject primitive Africanisms into a style which owed most to the nineteenthcentury English Romantic poets. However, other important Renaissance writers adopted a different approach and anticipated many of the concerns

6 See, for example, Ron Karenga, 'Black Cultural Nationalism ', Negro Digest, 17 (January 1968), 5 .

7 Nathan Huggins, Harlem Renaissance (New York, I97I), p. 85.

8 Cited in ibid., p. 205. 
and ideas of the more recent Black Arts Movement. Their work was often militant and preoccupied with the search for a genuine ethnic identity in the material of the Negro's folk culture and African heritage. Also, in the case of poets like Langston Hughes and Sterling Brown, one finds a genuine attempt to identify with and to celebrate the life-style of the black ghetto. In an essay published in 1926 Hughes wrote :

Most of my own poems are racial in theme and treatment, derived from the life I know ... it is the duty of the younger Negro artist... to change through the force of his art that old whispering 'I want to be white '. ... to ' why should I want to be white? I am a Negro - and beautiful '.

Hughes was concerned with much more than providing an exotic diversion for white Americans and proving that Negroes were capable of ' high culture'. Much more important and much closer to the mood of young writers in the cultural renaissance of the 1960 s were his pride in the black race, his belief that its lower classes 'furnish a wealth of colorful, distinctive material for any artist ...' 10 and his attempts to capture something of the vitality of this life-style through the use of dialect and street language.

Much closer to the Garvey movement in some of its fundamental concepts and its considerable influence among certain sections of the black community was the Black Muslim organization which was founded in the early ig3os and reached the height of its popularity and influence thirty years later. The Muslims were in fact highly critical of many aspects of the cultural renaissance, but in one important respect they prepared the way for it. Like Garvey before them, the Black Muslims preached an uncompromising doctrine of racial solidarity and black pride. For them blackness was not only beautiful, it was ' the ideal, the ultimate value '."

While the Muslims prepared the way for certain aspects of the upsurge of black consciousness in the latter part of the 1960 , there is some irony in the fact that the individual who most clearly anticipated many of the forms which this movement would take was someone who had actually broken with the Black Muslim organization. In a remarkable eleven months between his withdrawal from the Muslims in March 1964 and his assassination on 21 February 1965, Malcolm X was transformed from a black racist and a narrow-minded nationalist into an exponent of Pan-Africanism and something which came close to international socialism. In this same period Malcolm formed his own organization, The Organization of Afro-American Unity (OAAU), and travelled widely in Africa and the Middle East. He also evolved

\footnotetext{
9 Langston Hughes, 'The Negro Artist and the Racial Mountain ', in Addison Gayle, Jr, ed., The Black Aesthetic (Garden City, N.Y., 1971), pp. 179-80.

10 Cited in Huggins, op. cit., p. 204.

11 C. Eric Lincoln, The Black Muslims in America (Boston, 1961), p. 36 .
} 
and advocated certain ideas and objectives which together constitute a virtual blueprint for much of the cultural renaissance which developed soon after his death. More so than any of the other black leaders at that time, Malcolm grasped the central importance of culture and education to the black liberation movement. The OAAU's 'Statement of Basic Aims and Objectives' emphasized that ' Culture is an indispensable weapon in the freedom struggle. We must take hold of it and forge the future with the past.' ${ }^{12}$ The source of this culture was rooted in the African past. Malcolm stressed that 'We must recapture our heritage and our identity if we are ever to liberate ourselves from the bonds of white supremacy'. ${ }^{13}$ In a letter written in Ghana during May, 1964, he argued that even though Afro-Americans 'might remain in America physically while fighting for the benefits the Constitution guarantees us, we must " return" to Africa philosophically and culturally and develop a working unity in the framework of PanAfricanism '. ${ }^{14}$ The OAAU programme envisaged the implementation of a cultural revolution through the establishment of cultural centres and workshops in the black communities, and a Black Studies programme taught by black teachers in black-controlled schools. This, emphasized Malcolm, "is the means to help our children and people rediscover their identity and thereby increase self-respect ' ${ }^{15}$ It was with a similar end in view that he advocated the study of such languages as Swahili and Hausa. They would provide 'a direct access to the ideas and history of our ancestors...' ${ }^{16}$ In a speech delivered in January 1965 , Malcolm again anticipated future developments by denouncing the word 'Negro' on the grounds that it provided no identification with any country, colour, culture, language or history. 'As long as you call yourself a Negro, nothing is yours...? ${ }^{17}$

\section{II}

Malcolm X was assassinated before he could implement these policies, but the policies did not die with him. Malcolm played a central role in the growing consciousness and militancy of black people. The cultural ferment of the late 1960 s diverged from and went beyond what Malcolm had suggested, but it drew heavily on the broad outlines and even the specific details of his

12 From the OAAU's 'Statement of Basic Aims and Objectives', cited in John Henrik Clarke, Malcolm X: The Man and His Times (Toronto, 1969), p. 341.

13 Ibid.

14 Malcolm X, 'Letters from Mecca', in Barbour, op. cit., p. 244 .

15 John Henrik Clarke, op. cit., p. 337.

16 Cited in John Henrik Clarke, 'Malcolm X: The Man and His Times', Negro Digest, 18 (May 1969), 63.

17 Cited in John Henrik Clarke, Malcolm X: The Man and His Times, p. 323 . 
vision. An analysis of this movement definitely suggests that it was influenced by earlier precedents, but the fervour with which it was advocated, the variety of forms which it took and the degree to which it was implemented went far beyond anything that had gone before. For convenience the movement can be broken down into four main areas.

First, the African heritage was loosely interpreted and effectively exploited as a potentially rich source of ethnic pride. Black militants showed little interest in ascertaining the survival of genuine African influences in the language, music, religion and family structure of American Negroes, a subject which had engaged the interest of several generations of scholars. Their version of the African heritage was frequently over-simplified, distorted and artificial, but it furnished a valuable fund of imagery, symbol and myth. The central symbol was blackness itself, and identification with the pride and beauty of blackness was held to be inconsistent with the use of the term 'Negro'. Following in the footsteps of Malcolm X, H. Rap Brown described 'Negro' as 'a slave word' and he and Stokely Carmichael refused to speak to reporters who used the term. Moderates like Martin Luther King and Roy Wilkins were heckled and denounced for using the word. The most influential Harlem newspaper, the New York Amsterdam News, barred the word from its columns. ${ }^{18}$ As part of the re-emphasis of the African heritage Negroes were transformed into Afro-Americans or Blacks.

Another of Malcolm X's proposals, the study of Swahili, was partly implemented at this time amidst much controversy. Despite the obvious contradiction inherent in the descendants of slaves from Africa's West Coast seeking a new relationship with the mother-country through the study of a language spoken on its East coast, the movement spread. So too did the use of many other African-derived symbols of black identity and race pride. The midand late Ig6os saw a considerable vogue in the wearing of dashikis, bubas and caftans, and no ghetto was complete without a boutique specializing in the sale of African clothes, jewelry, sculpture and musical instruments. The most universal symbol of what one historian has described as the 'African cultural renaissance' 19 was probably the 'natural' or 'Afro' hair style, but for a small minority the 'Africanization' process extended as far as the holding of African style weddings, funerals, and religious ceremonies and the observation of African holidays. At the political level this new and much more positive relationship with Africa took the form of a renewed interest in the concept of Pan-Africanism, advocated by Malcolm X and many other black leaders before him. ${ }^{20}$

18 New York Times, 26 February, 1968, p. 31.

19 Robert G. Weisbord, op. cit., p. 188. Much of the material in this section is derived from Weisbord's study.

20 Ibid., p. 209. 
Related to these developments, but worth considering as a separate part of the cultural renaissance, was the Black Studies movement which swept American schools and colleges in the late sixities. In part, this movement was simply one aspect of an extremely widespread wave of student unrest and disruption which was both inter-racial and international, but to a far greater extent it both reflected and contributed to the period's increasing black militancy and awareness. Building on Malcolm X's understanding of the central importance of the right kind of education, the students involved in this movement demanded more community control of black schools and more student control of Black Studies programmes in universities. At the heart of the movement lay the belief that the traditional curricula were largely irrelevant to black needs and preoccupied with inculcating black students with white middle class values and aspirations, as a necessary prerequisite for integration into white society. Consequently the demand was for courses in black history, culture, literature and art - courses which would reflect the black experience and the African heritage, courses which would facilitate the development of a coherent cultural identity for black people. ${ }^{21}$ Critics were quick to point out the potential insularity of these trends and the danger that academic standards would be lowered and facts distorted for the purpose of creating usable myths and heroes, ${ }^{22}$ but the more perceptive advocates of Black Studies answered these criticisms and presented the possibilities of the movement in a much more positive way. The political scientist Charles Hamilton, for example, argued that Black Studies would do much more than simply provide 'catharsis-serving courses, intended only to beat Black chests and to blow white minds... I am suggesting that a true Black Studies program will go far beyond the necessary psychological value of selfidentity '. ${ }^{23}$ Hamilton and others were in effect arguing that Black Studies could and should be both functional and relevant to the practical as well as the psychic needs of the Black community. The movement should, for example, produce educated Afro-Americans, sensitive to the problems of their community and with the skills, expertise and motivation necessary to help solve these problems.

Among the changes envisaged by some advocates of Black Studies was the relegation of standard English to the status of a second language and the granting of due recognition in ghetto schools to what was often described

21 See, for example, Donald Henderson, 'Black Student Protest in White Universities', in John F. Szwed, ed., Black America (New York, 1970), pp. 263-5, and Frank Yates, 'Black Studies at this Juncture ', Negro Digest, 19 (March I970), 88.

22 For a critical view see Nathan Huggins, 'Afro-American History: Myths, Heroes, Reality', in Nathan Huggins, Martin Kilson and Daniel Fox, eds., Key Issues in the Afro-American Experience (New York, 1971).

${ }^{23}$ Charles V. Hamilton, 'Black Students Want Relevancy', Essence, I (May 1970), 25. 
as Black English. The language of white America was seen as important only for the practical purposes of communicating with and seeking employment in the dominant society. Black English was regarded as a symbol of black pride, a source of collective identity, and one expression of the complex, rich and unique culture which flourished in America's black ghettoes. ${ }^{24}$ The recognition and promotion of this 'Soul' culture constitutes an important third area of the black cultural renaissance.

The culture in question embraced every facet of ghetto life. Barbara Ann Teer has described it as 'the way we talk ... the way we walk, sing, dance, pray, laugh, eat, make love, and... the way we look', ${ }^{25}$ and there is no doubt that the symbolism and mystique of the 'Soul ' concept found powerful expression in many of these areas. The language of the street, unique in structure, content and in the facility with which it was used in the black community became the vocabulary of Soul, and effectively promoted a growing sense of identity, solidarity and belonging among its users. Traditional ghetto foods like chitterlings, collard greens and corn bread were transformed into Soul food and enjoyed a tremendous vogue as ethnic symbols. The more popular kinds of black music became known as Soul music. James Brown was Soul Brother Number One, and he reflected the increased level of black awareness by recording songs like 'Say It Loud: I'm Black and I'm Proud'. Not all Soul music was so socially conscious, but much of it embodied certain facets of the black life-style and acted as an important aid in the quest for solidarity, identity, pride and a new black consciousness. By the early Seventies something of the Soul ideology was evident in the film industry as a series of so-called 'black movies'. rescued the black man from previous cinematic obscurity and exploited the considerable status in the street hierarchy of the hustler and the pimp.

Critics of the 'Soul' phenomenon dismissed it as a commercialized escapist fantasy and maintained, with some justification, that ' stripped of its mystique, black culture is basically an American Negro version of lower-class culture '. ${ }^{26}$ This view, however, was only partly valid. It overlooked the degree to which the unique Afro-American experience had produced a culture which was genuinely ethnic as well as lower-class, and it underestimated the importance of 'Soul'. The concept of Soul - commercial, artificial and indefinable as it was - had publicized this culture and increased its importance as a powerful

24 These issues are discussed in Sheila Walker, 'Black English', Black World, 20 (June 1971), and June Jordan, ibid., 22 (August 1973).

25 Barbara Ann Teer, 'Needed: A New Image', in Barbour, op. cit., p. 222.

26 Bennett Berger, 'Black Culture or Lower-Class Culture', in Lee Rainwater, ed., Soul (Chicago, 1970), p. 127. See also Ulf Hannerz, 'The Significance of Soul ', ibid., pp. 26-8. New York Times, 3 May 1970, Il, p. 17, discusses the commercial exploitation of 'Soul ', and the African heritage. 
source of racial pride and solidarity and as a viable alternative to the cultural values advocated by those who favoured integration. ${ }^{27}$

One group of Blacks who recognized the validity and potential importance of ghetto culture and who sought to interpret, reinforce, validate and direct this culture, was the small, but extremely articulate, body of writers and musicians who comprised what they themselves frequently described as the Black Arts Movement. This movement, which emerged during the 1960 as ' the aesthetic and spiritual sister of the Black Power concept',${ }^{28}$ constitutes yet another element in the period's cultural renaissance.

The sound of jazz during the ig6os grew increasingly harsh, more vehement and more strident, more urgent and impatient. These qualities were apparent in the recorded work of influential musicians like Miles Davis, Sonny Rollins, Jackie McLean and John Coltrane. They were even more obvious in the work of many of the younger black avant-garde musicians some of whom quite consciously rejected the use of the term 'jazz' and identified their art as revolutionary black music. The music in question was black in the sense that it reflected the pain, degradation and anger of black men in racist white America, and revolutionary in its condemnation of this society and in its political overtones. Tenor saxophonist Archie Shepp, one of the most articulate spokesmen for the avant-garde, emphasized that ' $\mathrm{My}$ music is functional. I play about the death of me by you.' ${ }^{29}$ On another occasion he described recent black music as ' anti-war; it is opposed to Vietnam; it is for Cuba; it is for the liberation of all people...' ${ }^{30}$ This kind of commitment was certainly not shared by all black avant-garde musicians. Much of the music of John Coltrane, Sun Ra, Pharoah Sanders and Albert Ayler was characterized by a visionary, spiritual quality rather than any socio-political sensibility. This was especially marked in the case of Coltrane who recorded albums with titles like 'A Love Supreme', 'Meditations', and 'Ascension'. In a recent interview Elvin Jones has emphasized that Coltrane's music ' certainly wasn't any protest against anything. John was all love. Everything that he did was out of his love for music and his love for people.' ${ }^{31}$ Despite this degree of ambivalence and the different emphases in the period's most creative black music, much of it contributed to the attempt to implement a cultural revolution

27 In support of this view see Robert Blauner, 'Black Culture: Myth or Reality?', in Norman Whitten and John Szwed, ed., Afro-American Anthropology (London, 1970), and Charles Keil, Urban Blues (Chicago, 1966).

28 Larry Neal, 'The Black Arts Movement '; in Addison Gayle, Jr, op. cit., p. 272.

29 Cited in John Runcie, 'Black and Blue ', Luciad (March 1967), p. 15.

${ }^{30}$ Cited in Frank Kofsky, Black Nationalism and the Revolution in Music (New York, 1970), p. I4I. For Shepp's views see also John Runcie, 'Archie Shepp: Afro-America and the Black Counter Culture', Melody Maker, 2r September, 1974, p. $3^{\circ}$.

31 Cited in John Runçie, 'Elvin Jones - Drummer', Jazz Journal, 28 (April r975), 5. 
within the black community. LeRoi Jones, one of the chief exponents of the Black Arts Movement and one of the principal interpreters and defenders of the new music, was in no doubt as to its functional significance. Whether the implications of the music were political or spiritual it had moved beyond the realms of entertainment or pure art, and in Jones's opinion it could effectively engender self-interest and self-reliance within the black community and in doing so contribute to the raising of a revolutionary black consciousness. ${ }^{32}$ In an attempt to maximize the influence of the new music and to make it an integral part of ghetto life, Jones's Black Arts group organized mobile avantgarde jazz performances in the streets of Harlem during the mid-1960s. ${ }^{33}$

Concerns of this kind were also of central importance to many of the period's more radical black writers who formed the most important element in the Black Arts Movement. In their use of the traditional media of poems, plays and essays these artists provide the closest link between the cultural preoccupations of the 1960s and those of the 1920s, but in most cases their aims, objectives, priorities and methods were very different. The first priority for many of these artists was the conscious rejection of the conventions, standards and values of white western civilization and the creation of a radically different Black Aesthetic. Under the terms of this Aesthetic, black art would be created exclusively out of the experience of black life, would speak only to black people in a language which only they could appreciate and would ignore the expectations and reactions of white critics. The definers of the Black Aesthetic rejected the idea that self-expression was the highest priority of the artist and dismissed the concept of art for art's sake as ' something out of a Shakespearian dream '.${ }^{34}$ They condemned the idea of the existence of universal values and universal implications in art as ' a highly functional definition used by Europeans who attempt to impose their cultural values on others '.$^{35}$ Black art had various functions of its own to fulfil.

Of these, by far the most important was the potential role of art in the struggle for black liberation. For this purpose poetry and plays were to be written in the idiom of the ghetto and performed in the streets where they could achieve a certain intimacy with the people and not just the sophisticated élite. Larry Neal spoke for many when he proclaimed that:

the poet must become a performer, the way James Brown is a performer - loud, gaudy and racy. He must take his work where his people are: Harlem, Watts, Philadelphia, Chicago and the rural south... For the context of the work is as

32 Imamu Amiri Baraka (LeRoi Jones), 'The Ban on Black Music', Black World, 20 (July I971).

33 Nat Hentoff, 'The Life Perspectives of the New Jazz', Down Beat Music '67 Yearbook, pp. $23-4$.

34 Don Lee, 'Black Writing: this is u thisisu', Negro Digest, 18 (March 1969), 78.

35 Johari Amini, 'Re-Definition : Concept as Being ', Black World, 2 r (May I972), II. 
important as the work itself. Poets must learn to sing, dance and chant their works... We must make literature move people to a deeper understanding of what this thing is all about. . ${ }^{36}$

At one level 'this thing' was all about the celebration of blackness, the provision of a more positive self-image and the psychological liberation of black people through an art which would publicize black heroes and at the same time legitimize, without romanticizing, the lives of ordinary black people. ${ }^{37}$ For many, this was simply a necessary first step towards political liberation and revolution. LeRoi Jones summed up what was a principal tenet of the movement when he proclaimed that 'Black art means revolutionary art '. ${ }^{38}$

The advocates of the Black Arts Movement were the militant activists of black literature. They were determined to raise black consciousness beyond the simplistic assertion that 'Black is Beautiful' and beyond the limited symbolic satisfaction of growing an Afro hair style, wearing a dashiki and speaking Swahili. For them, literature was no longer an escape from reality, nor was it simply a protest, and they were as critical of James Baldwin as they were of Frank Yerby. The tone of the new Black Art was unremittingly aggressive, and its aims were the promotion of solidarity, strength, and confrontation. The inevitable outcome of this type of commitment was an intolerant fanaticism which at its most extreme dismissed all non-revolutionary art as invalid and irrelevant, ${ }^{39}$ and recommended a system of 'compulsory, subsidized theater with compulsory attendance? ${ }^{40}$

Inevitably the champions of the Black Aesthetic provoked a storm of critical reaction, much of it from established black writers. It was frequently depicted as a form of regimentation by literary commissars whose aim was to exercise group censorship over the arts and to eliminate artistic freedom of expression. The well-known black poet Robert Hayden accused LeRoi Jones of 'black nazism ',"1 James Baldwin complained of a black cultural dictatorship, ${ }^{42}$ and Ralph Ellison condemned the Movement as an attack on the unique individuality of the artist. ${ }^{43}$ These were but a few of the criticisms

36 Larry Neal, 'And Shine Swam On', in LeRoi Jones and Larry Neal, eds., Black Fire. An Anthology of Afro-American Writing (New York, 1968), p. 655.

${ }^{37}$ See, for example, Clayton Riley, 'On Black Theater' in Gayle, Jr, op. cit., pp. 315-27.

38 Imamu Amiri Baraka (LeRoi Jones), 'Black Revolutionary Poets Should Also Be Playwrights ', Black World, 21 (April I972), 4. See also New York Times, 5 January 1968, i, p. 33, for an account of Jones's involvement in the Newark riot of 1967 .

39 Ron Karenga, 'Black Cultural Nationalism', Negro Digest, 17 (January 1968), 5, 9.

40 Bruce Milliam, cited in Helen Johnson, 'Playwrights, Audiences and Critics', Negro Digest, 19 (April 1970), 23.

4 Robert Hayden, in excerpts from a writers' symposium, Negro Digest, 17 (January 1968), 33. 42 James Baldwin, from an interview in Essence, 1 (October 1970), 27.

13 Ralph Ellison, 'Romare Bearden: Paintings and Projections ', Crisis, 77 (March 1970), $8 \mathrm{I}-86$. 
levelled at the Black Arts Movement in the course of what developed into an extremely acrimonious debate. Writing in the New York Times, John Leonard injected a badly-needed note of humour into the proceedings when he referred to 'the fried chicken franchise approach to creativity', and compared the idea that only Blacks were capable of evaluating black literature to "the suicide implicit in sending "Moby Dick" out for reviews only to sailors, or to singing whales...', 44

Understandably the Black Arts Movement gained much less publicity than the Soul boom or the popularization of the African heritage. It offered little potential to the commercial exploiters and its implications were much more threatening. Despite this the Movement made itself felt. Black Arts groups were formed in the ghettoes of many major American cities and on many university campuses. For a while it looked as though poets might become the new culture heroes in the black community. ${ }^{45}$ No matter what its critics felt, the Black Arts Movement played a most important role in the cultural renaissance which hit Black America in the 196os.

\section{III}

The significance and implications of these various developments on the cultural front are perhaps most accurately measured by analysing the reaction to them of the more important protest organizations operating in the black community. The organizations in question range from biracial integrationist groups like the National Association for the Advancement of Colored People and the Urban League, to black separatists like the Congress of Racial Equality and the Black Muslims; from revolutionary nationalists like the Black Panthers to cultural nationalists like US. Predictably the reactions were as different as the organizations themselves, ranging from unqualified acceptance through ambivalence to almost complete hostility. However it is a measure of the impact of the cultural renaissance that throughout the entire spectrum of these very different groups there was not one which remained totally untouched by some aspect or other of it.

The new emphasis on black consciousness found its most enthusiastic acceptance in the writings and activities of the cultural nationalists, many of whom were deeply involved in defining the theoretical basis of the Black Arts Movement and in implementing their ideas through the formation of arts societies and theatre groups. The cultural nationalists are probably best represented in the person of Ron Karenga - community organizer, leading participant in the Black Power conferences of $1966-68$, and co-founder in

14 New York Times, 13 February, 1972, vil, p. 47.

45 Hollie West, 'Black Poets Reach Back to the Streets', Black Times, I (August 1971), 6. 
1965 of the organization which he called US. With a master's degree in political science from the university of California and a definite gift for the use of militant rhetoric, Karenga was well equipped to formulate the ideology of cultural nationalism. The essence of this ideology was that 'Black people in this country make up a cultural nation', that 'there must be a cultural revolution before the violent revolution', and that this revolution was impossible without 'self-determination, race pride and the pursuit of Blackness'. As part of this process Karenga urged Afro-Americans to "Think Black, Talk Black, Act Black, Create Black, Buy Black, Vote Black, and Live Black'. $\mathrm{He}$ and his organization embraced every facet of the cultural renaissance. They made much of the richness of ghetto culture, supported the demand for autonomous Black Studies and emphasized the role of the arts in the liberation struggle. On the grounds that 'We don't borrow from Africa. We utilize that which was ours to start with', ${ }^{46}$ they also encouraged the learning of Swahili, the wearing of African clothes, the use of African names (Karenga now became Maulana Ron Karenga), the observation of African holidays, and the practice of an African-influenced religion. ${ }^{47}$

The cultural nationalists were exceptional in the fervour with which they embraced and attempted to implement every aspect of the renaissance. The reaction of other organizations was much more variable, but even the most sceptical were prepared to make certain concessions and to offer at least token recognition to the cultural self-consciousness which was so obviously growing in the black community. Among the more militant groups, the Student NonViolent Co-ordinating Committee (SNCC) came closest to the position of the cultural nationalists. This was especially true during the period in which Stokely Carmichael was the organization's chairman. In 1966, when he first emerged as a national figure, Carmichael repeatedly emphasized the urgent need for psychological equality and increased black consciousness among Afro-Americans. In a speech delivered in Cuba the following year, he argued that 'Color and culture were and are the key in our oppression... Black Power not only addresses itself to exploitation but to the problem of cultural integrity ' ${ }^{48}$ It was presumably with considerations of this kind in mind that Carmichael and his successor, Rap Brown, sought to proclaim their blackness

46 This and previous quotations are from Clyde Halisi and James Mtume, eds., The Quotable Karenga (Los Angeles, $19^{6} 7$ ).

47 Robert G. Weisbord, op. cit., p. 20I. For the transformation of US into the Temple of Kawaida and the development of Karenga's ideas on cultural nationalism into the doctrine of Kawaida see Ron Karenga, 'Overturning Ourselves: From Mystification to Meaningful Struggle', Black Scholar, 4 (October 1972), and 'A Strategy for Struggle', ibid., 5 (November 1973).

48 Cited in John Henrik Clarke, 'Black Power and Black History', Negro Digest, 18 (Feb. ruary 1969$), 14$. 
and their disregard for white values by appearing frequently in African clothes and refusing to recognize the word Negro. SNCC's interest in cultural nationalism was apparent also in Julius Lester's book Look Out Whitey! Black Power's Gon Get Your Mama. By the time the book was published in 1970, SNCC itself had ceased to exist, but Lester, an ex-field secretary of the organization, reflected the views it had held prior to its disintegration. In a chapter specifically devoted to cultural nationalism he analysed the unique qualities of black culture and dismissed as irrelevant the Western concept of art for art's sake. Following in the footsteps of Karenga, Jones, and others, Lester argued that in the black community "The artist is essentially a revolutionary whose aim is to change people's lives '. ${ }^{49}$

One of the difficulties in discussing SNCC is that it lacked a clearly defined ideology and an effective organizational structure. This disunity raises the possibility that individuals like Carmichael and Lester spoke for themselves rather than for all SNCC members. This was much less of a problem with other black militant groups, most of which were tightly organized and clear as to their philosophy. Cultural considerations were not of paramount importance to any of the organizations in question, but the force of the renaissance was too great to be ignored.

The Black Muslims were a case in point. Their attitude to many facets of the black consciousness movement was ultimately extremely ambivalent; even hostile, but this is not immediately apparent in the coverage given to the subject in the pages of Muhammad Speaks, during the period 1967-69. The paper carried innumerable reports on the growing student demand for Black Studies programmes. ${ }^{50}$ Attention was also focussed on the activities of black writers, painters and musicians. The Muslim newspaper endorsed some of the ideas of the Black Arts Movement when it discussed the "mounting awareness of Black art as an articulate voice in the freedom struggle and a cohesive force toward Black unity'. ${ }^{51}$ On different occasions the paper contained poems by LeRoi Jones, ${ }^{52}$ a full-page photograph and obituary on John Coltrane, ${ }^{53}$ and progress reports on black arts groups like the Negro Ensemble Company in New York..$^{54}$ It carried articles which discussed the possibility that the right kind of theatre 'might well be the blitzkrieg of the Black revolu-

49 Julius Lester, Look Out Whitey! Black Power's Gon Get Your Mama (London, 197o), p. 88.

5. See, for cxample, Muhammad Speaks, 18 October 1968, p. 25, and 20 December I968, p. I3.

51 Ibid., I I October 1969, p. 37; see also 20 December I968, p. 37.

52 Ibid., 3I May I968, p. 29.

53 Ibid., 28 July, I967.

54 Ibid., 20 December r968, pp. 37-8. 
tion ', ${ }^{55}$ and described avant-garde jazz as ' the song of growing warriors, the inspirational hymn of a new breed of people demanding manhood... ${ }^{56}$ Soul music also came in for some attention. When James Brown's record 'Say It Loud: I'm Black and I'm Proud ' was released in I968, Muhammad Speaks carried several full-page advertisements complete with a photograph of Brown, the full lyrics of the song, and appropriate comment on its role in promoting black pride and dignity. ${ }^{57}$ In this context the increasing interest in popularizing and exploiting the African heritage was not entirely overlooked. The Muslim movement had for many years been urging its women to renounce artificial aids and make the most of their natural beauty. It was consistent with this attitude that a May 1968 edition of Muhammad Speaks should carry an illustration of a fairly moderate 'Afro' hairstyle and note that the style was 'being affected by many Black women and young girls who have grown tired of psychotic attempts to attain a white look with hot irons and chemicals '. ${ }^{58}$ The willingness of the Muslims to move with the times was also apparent in the 'Black Pride' advertising which their paper carried during this period, and here too the African heritage theme appeared occasionally. ${ }^{59}$ However sceptical the Muslims may have been about much of the cultural renaissance, part of it, at least, was consistent with the essence of Elijah Muhammad's message, which leading Muslim minister Louis Farrakhan described as 'pride in blackness, trust in blackness, love for blackness '.60

This much at least of the Muslim philosophy was shared by the Congress of Racial Equality both before and after its conversion from integration to racial separatism and Black Nationalism in 1968. Under the leadership of Floyd McKissick, CORE's freedom schools offered Black Studies courses on the grounds that familiarity with the Afro-American's history and culture would increase his awareness and provide him with a more coherent identity ${ }^{61}$ Both McKissick and his successor Roy Innis also supported the movement for the teaching of Swahili in the American public school system. They saw it as a language with which black children could identify, and this, as Innis

55 Ibid.

56 Ibid., 25 August 1967, p. 21.

57 Ibid., 13 September 1968, p. 23; 20 September 1968, p. 23.

58 Ibid., 3 May i 968 , p. 21.

59 Ibid., 10 January 1969, p. 35. I7 January r969, p. Io; 18 September 1970, p. 21; and 25 December 1970, p. 28, contain advertisements for Black Power Cologne, Black Power After Shave, the 1969 Calendar of Soul (with illustrations of Jomo Kenyatta and Patrice Lumumba), Black is Beautiful Sweatshirts and Amulets containing genuine soil from Mother Africa'.

60 New York Times, 15 April 1972.

61 Floyd McKissick, 'Programs for Black Power', in Barbour, op. cit., p. 180. 
put it, would contribute 'toward improving the badly-eroded self-image of black people '. ${ }^{62}$

Innis was well aware of the danger that exploitation of the African heritage might become an end in itself and simply create an illusion of change. Under him CORE's policy concentrated on the winning of social, economic and political independence for the black communities of America with a view to the ultimate unification of these communities into a single national political entity. Despite these priorities CORE did not completely abandon the concerns of the cultural renaissance and the organization actively developed the African connexion. At one level this involved Innis's attendance at the Tenth Anniversary Meeting of the Organization of African Unity, but it also involved the implementation of a programme of 'pilgrimage flights' to the 'Motherland ' which CORE justified on the grounds of ' the spiritual and educational benefits of such a visit to our ancestral home, Africa ... ${ }^{63}$ The spirit of black pride was still a central concern for CORE, and this was only fitting as its leaders had specifically adopted Marcus Garvey's ideology in its entirety. ${ }^{64}$

Of all the black militants, the Black Panthers were the most outspoken critics of the new emphasis on black consciousness and race pride, but even they were able to adapt certain aspects of the cultural renaissance to their class analysis of the black situation and to their socialist principles. As the selfappointed heirs of Malcolm X, the Panther leaders could hardly ignore his emphasis on the importance of black culture, and from its earliest days the party showed an interest in familiarizing the black community with its heritage and its history. As early as 1967 the Panthers were teaching classes in black history, and as recently as 1974 their newspaper carried the banner headline 'Celebrate Black History'. On that occasion the paper's editorial condemned racist America for continuing 'to deny Black children access to the glorious history of Black people in America and the world ', ${ }^{65}$ and proposed to remedy this situation by including a regular black history column in its pages. That this was more than a celebration of blackness for its own sake was apparent from the decision to include material only on those militant black heroes who had 'served the masses of Black people'.

The Panthers also realized full well the potential value of art as propaganda in the education of the masses for revolution. For all their bitter criticism of the cultural nationalists, the Panthers sometimes came close to the theories of the Black Arts Movement in their condemnation of the idea of art for art's sake as a bourgeois irrelevance. ${ }^{66}$ They were in fact contemplating a visual

62 New York Times, 15 January I968, p. 46; 4 Fcbruary 1968, vi, p. 28.

63 Core Magazine, 3 (Fall/Winter I973), 5.

64 For an analysis of CORE's policies and the debt which they owe to the ideology of Marcus Garvey, see Ed Brown, 'Core and Garveyism ', ibid., pp. 4I-3.

65 The Black Panther, 9 February 1974, pp. I-2. 66 Ibid., I8 May i974, p. 4 . 
equivalent to some of LeRoi Jones' poetry in their demand for 'Pictures that show black people kicking down prison gates - sniping bombers, shooting down helicopters, police, mayors, governors, senators, assemblymen, congressmen, firemen, newsmen, businessmen, Americans... pigs lying in the alley ways of the colony dead with their eyes gouged out...? ${ }^{6 \tau}$ The Panthers also showed understanding of the strong non-literate, oral bias of black ghetto culture by attempting to use music as another weapon in what they saw as their revolutionary struggle. The Black Panther Deputy Minister of Information, Elaine Brown, described by Huey Newton as ' the first genuine People's Artist America has produced ', ${ }^{68}$ has issued several recordings of political protest songs. These various Panther activities definitely suggest the influence of the cultural renaissance occurring in the black community, but they also indicate the degree to which the Black Panthers remained on the periphery of this movement. The Panthers were aware of the need to increase the level of the Afro-American's self-image, but their main aim was not the promotion of black consciousness so much as a Marxist-Leninist inspired working-class consciousness.

The impact of the cultural renaissance on the more militant wing of the black protest movement was hardly surprising. Black Power itself was always more of a unifying symbol and an emotive slogan than a coherent ideology or a clearly defined programme, but despite all the contradictions and ambiguities inherent in the concept, the emphasis on race pride and black consciousness was clearly central to it, and few militants could ignore this fact. Nor, it would seem, could those organizations which with the rapid progress of events were identified as the moderates or even the conservatives of black protest. Even in those circles where the main aims were the winning of civil rights and the creation of a fully integrated society, where the philosophy was that of non-violence, and the rallying cry was 'We shall overcome', the cultural renaissance was a force which had to be recognized, however reluctantly.

The Southern Christian Leadership Conference (SCLC) and its leader Martin Luther King, are a case in point. In his book Chaos or Community? published in 1967 , King, without any change in his philosophy or his objectives, moved with the times and welcomed the determination of the militants ' to glory in blackness and to resurrect joyously the African past' ${ }^{69} \mathrm{King}$ went on to describe the Afro-American as the victim of a form of "cultural homicide ${ }^{70}$ at the hands of a society which had rendered him invisible by

67 Philip S. Foner, ed., The Black Panthers Speak (Philadelphia, New York, 1970), p. 18.

68 The Black Panther, 18 May 1974, p. 4.

69 Martin Luther King, Choos or Community? (New York, 1967), p. 57.

70 Ibid., p. 46 . 
ignoring his contribution to its history, science and culture and by alienating him from his own culture. Too many Negroes, King argued, sought ' to reject their heritage, are ashamed of their color, ashamed of black art and music, and determine what is beautiful and good by the standards of white society ' ${ }^{71}$ By 1967 King was in fact agreeing that the winning of civil rights legislation was in itself an incomplete solution to the Afro-American problem. Only psychological liberation and a much more positive self-image would enable the Negro to say 'I am somebody. I am a person. I am a man with dignity and honor... I am black and comely!' ${ }^{2}$ Martin Luther King was assassinated before he had the chance to show to what extent the insights which the cultural renaissance had given him into the black problem would be accompanied by the solutions which it offered. However, there are indications that the SCLC at least flirted with some of those solutions. It was notable, for example, that although there was no fundamental change in the organization's policies, the atmosphere at its thirteenth annual convention in $197^{\circ}$ was more militant than usual and the delegates showed increased interest in the promotion of black identity. Many of the younger delegates wore Afro hair styles and dashikis and the sound of soul music had replaced the traditional rendering of 'We Shall Overcome'. According to the New York Times, 'The keynote has become soul power in a bright African-styled shirt'. ${ }^{73}$

Similar trends were also evident within the Urban League, one of the oldest, largest, most influential and most moderate of the civil rights organizations. In 1967 the New York branch of the Urban League launched a shortlived magazine called Probe which indicated a new interest in militant rhetoric and cultural nationalism. Probe endorsed the recent trend towards African style clothes as a welcome source of pride and dignity for AfroAmericans, and interpreted the boom in 'Soul Food' as the revival of a valid cultural tradition. ${ }^{74}$ The magazine also devoted much of its space to the work of black musicians and writers and emphasized the important role of the artist in raising the level of awareness within the black community. Probe's readers were admonished to reject the dominant culture, to refrain from hair-straightening or inter-marriage, and to remember that they were 'from the womb of Africa. This is the foremost fact - that we are African Americans. We should begin to act like it.' ${ }^{75}$ In accordance with this view, the New York Urban League provided $\$ 70$,ooo in the summer of I968 to finance what was described as an African Summer Safari project. Twenty-

71 Ibid., p. 57.

72 Ibid., p. $4^{8}$.

73 New York Times, 16 August 1970, p. 56.

74 The Probe, I (May I967), pp. 20-2.

75 Ibid., I (Winter 1968), 23. 
five Harlem youths, most of them high-school drop-outs, were sent to stay with families and meet political leaders in various African countries. The twoand-a-half month trip was designed to familiarize the youths with their African heritage. ${ }^{76}$ This new kind of emphasis was not confined to local branches of the Urban League. On 7 July I 968 its National Director, Whitney Young, gave an hour-long speech at the annual CORE convention in which he argued that Negroes were ' no longer enchanted with being near white people', and identified the Urban League with ' that interpretation of black power that emphasizes self-determination, pride, self-respect and participation and control of one's destiny and community affairs ' ${ }^{77}$ This convention was the occasion of CORE's conversion to black separatism and raises the possibility that Young's speech was tailored to suit its audience. It was certainly greeted with a standing ovation and with cries of 'The brother's come home'. However, the change in Young and the Urban League was more apparent than real. Despite its much publicized 'new thrust' the League's I968 and 1969 conferences were disrupted by some of its younger members who succeeded, among other things, in committing the League to support for the concept of separate Black Studies programmes. ${ }^{78}$ Even these efforts produced no radical transformation in the Urban League. It remained what it had always been - an organization largely financed by funds from the federal government and from powerful white foundations, involved in trying to solve black urban problems in such fields as unemployment, health and education. The relevant point, however, is not that the League retained so much of its traditional character but that the cultural renaissance exerted as much influence within the organization as it clearly did. ${ }^{79}$

The same argument applies, although on a much lesser scale, to the largest and most famous of all the black protest organizations, the National Association for the Advancement of Colored People. The NAACP retained its character as a middle-class, biracial organization dedicated to assuring the Negro's civil rights and improving his status in an integrated society, primarily by the use of legal and legislative action. However, even the NAACP did not remain entirely untouched by the progress of the black cultural renaissance. One has to look fairly hard to find proof of this but the evidence is available, although it usually takes the form of a restatement of traditional NAACP policies in such a way as to defend the organization from the mount-

76 New York Times, 26 June I968, p. 32.

77 Ibid., 7 July 1968, pp. I, 38.

78 Ibid., I August I968, p. 48; 3 August 1969, p. 42.

29 In an interview published in the National Observer, 9 March $x 974$, Whitncy Young's successor, Vernon Jordan, voiced his support for self-determination, ethnicity, and cultural pluralism. 
ing criticism levelled against it by the more militant advocates of cultural separatism. It was a sign of the times, for example, that the Association's journal, The Crisis, emphasized that it would not accept advertisements for hair-straightening or skin-bleaching products. ${ }^{80}$ Also significant were claims by the journal's editor that since its founding The Crisis had consistently tried to promote racial pride by publishing material on black heroes and on 'Negroes of achievement, both African and American ' ${ }^{81}$ Roy Wilkins, the NAACP's executive director, made a similar point early in 1969 when he emphasized that the organization had always advocated a form of black power by consciously attempting to foster political power, economic power, and race pride among Negroes. Wilkins also expressed NAACP support for African and Afro-American studies, so long as they were taught by qualified staff on an integrated basis. ${ }^{82}$ These statements may have had something to do with the fact that, like the Urban League, the NAACP had had trouble with its younger and more militant members at its 1968 convention. The youth delegates wanted the NAACP to take a greater interest in black culture and hoped to make the organization ' more relevant to the Negro community and to the revolution in the streets ${ }^{83}$ Eventually 600 of them walked out of the convention. ${ }^{84}$

\section{IV}

This incident helps to put the position of the NAACP into a more accurate perspective. The influence of the cultural renaissance was too great to be ignored and the NAACP did support certain facets of it. But the support was always extremely selective and highly qualified, and the characteristic response of the organization was to criticize and attack virtually every aspect of the renaissance. The NAACP was not alone in this hostility. Ultimately the cultural renaissance began to founder because of its own inherent weaknesses and because of changing circumstances outside the black community and altered priorities within it, but there were other factors involved. Of these the most important was the mixed response to the movement of certain key black organizations. Not one of these groups dissociated itself completely from the implications of the renaissance, but in several notable cases their acceptance of its various theories and activities was minimal and their overall reaction was scathingly critical. This hostile reaction came in particular from the Black Muslims, the Black Panthers and the NAACP, and it is worth examining them separately since each of these organizations attacked the cultural renaissance for very different reasons.

80 The Crisis, 76 (February 1969), p. 6r.

81 Ibid., 74 (November 1967), p. 440.

82 Ibid., 76 (February 1969), p. 84.

83 New York Times, 25 June 1968, p. 29.

84 Ibid., 29 June I968, p. 26. 
In the case of the Muslims the attack came from a black separatist organization which was so insular and self-contained, so self-sufficient in terms of its structure and ideology, and so uncompromising in its acceptance of this creed, that it was almost bound to criticize any development which conflicted with its own unique interpretation of the black situation. For this reason the attitude of the Muslims to the cultural renaissance was extremely ambivalent. As described earlier, the black consciousness movement was discussed at length in the pages of Muhammad Speaks, but when this material is examined more carefully it becomes apparent that much of it has a certain pro-Muslim bias. The artists reviewed in the paper were frequently Muslims. When the paper published poems by LeRoi Jones they were poems which praised the Muslim hero, boxer Muhammad Ali, and emphasized the superior strength of Allah in comparison to the Christian God..$^{85}$ The publicity given to singer James Brown is possibly explained by his pro-Muslim sympathies. ${ }^{86}$ Coverage of the Black Studies movement was consistent with point nine of the Muslim Programme which stated 'We want all black children educated, taught and trained by their own teachers'. It was also marked by a readiness to draw attention to the success of the Muslim organization in implementing this policy among its own members. ${ }^{87}$ This type of reaction extended beyond the field of Black Studies. The Muslims were not averse to appropriating the credit for fostering those aspects of the cultural renaissance of which they approved. On one occasion Elijah Muhammad's son Nathaniel emphasized that 'Ever since I931 our Divine Messenger has been teaching that Black is Beautiful'. He went on to argue that many of the ideas then circulating in the black community had been stolen from his father.$^{88}$

This attitude did not embrace every aspect of the cultural renaissance. When the movement contradicted or threatened Muslim beliefs or practices it was subject to scathing criticism. Their attitude to the culture of 'Soul ' illustrates this point effectively. Despite the publicity given to James Brown the Muslims' rejection of the attempt to establish the richness of the ghetto culture and transform it into the mystique of 'Soul' was entirely predictable. The Nation of Islam offered an alternative to the black subculture, not an endorsement of it. One of the basic ironies of the Muslim movement is that while it totally repudiates the white man and his institutions, it has almost completely accepted the Puritan ethic of hard work, thrift, discipline and morality. Consequently the Muslims, like certain sociologists, tend to see the life-style of the ghetto as a culture of poverty, characterized by hedonism, violence, opportunism and degradation, from which they offer redemption

¿5 Muhammad Speaks, 31 May 1968, p. 29.

86 Ibid., 4 October 1968, p. 7 .

87 lbid., 29 November 1968, p. $3^{\circ}$.

88 Ibid., 27 December 1968 , pp. 20-2. 
and moral rehabilitation. The ascetic life-style of the Muslims, with its ban on the use of alcohol and tobacco and its stringent sexual morality, is in sharp contrast to standard ghetto behaviour, and this gap is reinforced in other ways. Even something as apparently innocuous as the fashionableness of Soul food was roundly condemned by the Muslims. Their dislike of pork was predictable, but Elijah Muhammad also scorned the use of many other typical ghetto foods including lima beans, black-eyed peas, collard greens, corn bread, hominy grits, and sweet potatoes. To the Muslims, Soul food was fit only for animals and slaves, and the 'Great Poison Dishes' as Muhammad described them were seen as anything but a valuable symbol of black identity. ${ }^{89}$

By 1970 the Muslims were equally critical of those aspects of the cultural renaissance which sought to promote ethnic identity through the exploitation of the African heritage or the encouragement of Black Studies programmes. Elijah Muhammad spoke scathingly of those Afro-Americans who were 'not using barber's tools, shears and razors to keep themselves looking dignified as a civilized people should be. The Black Man in America accepts the jungle life, thinking that they would get the love of Black Africa'. He went on to warn the gullible black community that 'wearing savage dress and hairstyles will not get you the love of Africa '.90 The Muslims, it seemed, were still influenced by the once popular myth of Africa as a land of jungle and savages. Their clothes, like their morality, were those of middle-class America. The dashiki did not replace the sober Ivy League suit. The Muslims had no time for what they dismissed as 'superficial fake images of Blackness' and tended to view the new trend as a dangerous diversion which was encouraged and subsidized by the white power structure out of self-interest." This same conspiracy theory was sometimes also apparent in the Muslim view of Black Studies. They believed that many Black Studies programmes were being funded by the CIA or by such bodies as the Ford and Carnegie foundations, partly as a control mechanism to keep the ghettoes quiet, partly to provide research data for use in the neo-colonial control and exploitation of Africa. ${ }^{92}$ The Muslim view of Black Studies and the Soul concept as potentially dangerous and certainly irrelevant to black needs is summed up in a Muhammad Speaks cartoon in which a black youth is told "You got a " $\mathrm{C}$ " in spelling ..., a " $\mathrm{D}$ " in Arithmetic ..., an " $F$ " in Art ... but an " $\mathrm{A}+$ "

89 Ibid., zo March 1970. See also 29 November 1968, p. 37, in which Muhammad asked 'How can a particular food make one more black when its purpose is assimilation for nourishment, not pigmentation for improvement?

90 Ibid., 22 May 1970, p. 17.

91 Ibid., 10 July 1970, p. 24.

92 lbid., ir September 1970, p. 3. See also 2 October 1970, pp. II-12. 
in "Soul", ${ }^{93}$ The Black Muslims were extremely sensitive to the need for encouraging self-respect and racial solidarity within the black community, and to the importance of providing Afro-Americans with some realization of their past history and culture. The cultural ferment in Black America undoubtedly increased Muslim interest in these areas, but the solutions which they offered to these problems were as unique as their interpretation of black history, and both were far removed from the central concerns of the cultural renaissance.

Despite their belief in the importance of building a deeper awareness of black culture and black history, the Black Panthers were among the most vociferous critics of the cultural renaissance. They shared with the Muslims the belief that the movement was condoned and encouraged by the white power structure as a harmless means of pacifying the ghettoes. The former Panther Minister of Education, George Murray, voiced the party line when he condemned the cultural renaissance as 'a bourgeois-capitalist scheme to confuse the masses of people, so that they will not assault the city halls, the bank tellers and managers, or seize control of community schools '. ${ }^{94}$ This, however, was the extent of the similarity between the attitudes of the two organizations, and even on this point it was clear that the Panthers' disillusionment stemmed from an ideology which was completely different from that of the Muslims. The Panthers' Marxist-Leninist-inspired view of the black situation conditioned them to interpret white involvement in the cultural renaissance in terms of a subterfuge by the bourgeoisie to avert a potentially revolutionary situation, while at the same time exploiting the commercial possibilities of Soul music, African clothes and other 'cultural ' artifacts. ${ }^{95}$

The Black Panthers' attack on cultural nationalism breaks down into several different, although related, categories. In the first place they viewed as absurd the idea that wearing dashikis and Afro hair styles, or learning to speak Swahili, was genuinely cultural, and ridiculed 'the fools running round ... who tell the black people that they should relate to African customs and an African heritage that we left three hundred years ago ... ${ }^{96}$ The Panthers also argued that this 'Africanization' was much more popular among the black bourgeoisie than among the average ghetto blacks. Eldridge Cleaver, in particular, has described cultural nationalism as largely the creation of university-educated middle-class blacks like Ron Karenga and LeRoi Jones, for whom it was a necessary means of re-establishing contact with their black roots. ${ }^{97}$ This in itself is not necessarily a bad thing in the Panther view

93 Ibid., 13 November 1970, p. 12.

94 The Black Panther, 3 March 1969.

$9.5 \mathrm{See}$, for example, Foner, op. cit., p. 152.

96 The Black Panther, 25 May 1969, p. 4.

${ }^{97}$ Lee Lockwood, Conversation with Eldridge Cleaver/Algiers (London, 1971), pp. I11-12. 
so long as it only represents a transitional phase and does not become an end in itself. However, despite all the pronouncements of people like Karenga that the cultural revolution was simply a necessary prerequisite to the violent revolution, the Panthers have consistently condemned cultural nationalism as counter-revolutionary. They tend to view it as militant only in its rhetoric and therefore no more than a passive substitute for the kind of action which would improve conditions in the ghettoes. As one Panther put it, 'We don't mean to get hung up studying Swahili for the next sixteen semesters while we are being oppressed, suffer unemployment, low paying jobs, high taxes, high cost of living, war after war, and police brutality '. ${ }^{98}$ To the Panthers even the militant writers of the Black Arts Movement were essentially bourgeois rhetoricians, hailed by establishment publications like the New York Times, Time Magazine and Newsweek rather than by the black masses. They advocated the study of Marx rather than Swahili, for as Huey Newton saw the situation, 'culture itself will not liberate us. We're going to need some stronger stuff '.99 For Newton and the Panther party the posturing of the cultural nationalists was no substitute for the revolutionary culture which would arise out of resistance to political, social and economic oppression. Influenced by the ideas of Frantz Fanon, they also believed that revolutionary violence offered by far the most promising source of black pride and dignity. ${ }^{100}$ However, the revolution which the Panthers envisaged was not to be an exclusively black affair and this was the source of yet another important area of disagreement between them and the cultural nationalists. The Panthers were fond of pointing out that exploitation, repression, and poverty were not a black monopoly. Eldrige Cleaver expressed their attitude in a 1969 letter to Stokely Carmichael when he wrote 'You know that suffering is color-blind, that the victims of Imperialism, Racism, Colonialism and Neo-Colonialism come in all colors, and that they need a unity based on revolutionary principles rather than skin-color'. ${ }^{101}$ The Panthers were committed to the MarxistLeninist idea of proletarian internationalism and therefore to the possibility of alliances with white revolutionaries. This point of view was irreconcilable with the cultural nationalists' insistence that the key to the black struggle was race rather than economics or class, and the willingness of some of them to dismiss Marx as irrelevant on the grounds that he was a white man. ${ }^{102}$

The NAACP was another organization which disliked the racism implicit

98 The Black Panther, 31 May 1969.

99 Foner, op. cit., p. $5^{0 .}$

100 Ibid., p. xvi.

101 lbid., p. 105.

102 Julius Lester, op. cit., p. 79. For the racist element in cultural nationalism, see Foner, op. cit., p. 153 . 
in much of the cultural renaissance and saw the movement as a threat to the co-operation with white people on which many of its activities were based. This, however, was the extent of any similarity between the NAACP and the Black Panthers. The ideologies and objectives of the two organizations were as different as the white allies they both sought. The NAACP had no wish to foster divisions within American saciety, either on the basis of class or race. Like other moderate civil rights groups, its central concern was the acceptance of the Negro as an equal in all phases of American life. The NAACP believed that despite his colour and his ancestry, the American Negro was fundamentally American and that the only possible future for him lay in an America which accepted the principles of integration and equal opportunity for all. Inevitably it found fault with virtually every aspect of the cultural renaissance.

The theories of the Black Arts Movement were roundly criticized from the pages of The Crisis by people like Ralph Ellison and Bayard Rustin, who poured scorn on the idea that black artists should create only for other Blacks or that there should be separate standards for black art. From the NAACP point of view great art transcended considerations of race, propaganda or ideology, and Rustin could only lament that so many young Blacks were 'attempting to be artists without having any discipline' and were ' accepting inferior art on the basis that it is " black art" '. "There is no such thing', he continued, ' as black art independent of artistic standards. An inferior drawing is inferior no matter who did it, no matter how black the creator is, no matter how long his hair, no matter how he dresses.' ${ }^{103}$

Similar feelings about the universality of human experience and about the dangers of exploitation by a particular ideological group influenced NAACP reactions to the Black Studies movement. The organization did not object to the study of Negro history and culture as such, but to the demands that such study should be restricted to black students and black teachers and conducted in separate black facilities. These demands were denounced as a form of black racism. Roy Wilkins used the word apartheid in this context and made it clear that the NAACP would oppose segregated Black Studies programmes in the courts as a form of Jim Crow. There were additional fears within the organization that although Black Studies might improve the selfimage of the individual Negro they might also limit his career prospects and deprive the community of the skills it so badly needed. ${ }^{104}$

103 The Crisis, 77 (August-September 1970), 260-3.

104 For Wilkins' views see The Crisis, 76 (February 1969), 84, and the New York Times, I4 January 1969, 1. Also useful were, Francis Rivers, 'Black Nationalism on the Campus', The Crisis, 75 (April 1968), and Martin Kilson, 'The Black Studies Movement: A Plea for Perspective ', ibid., 76 (October I969). 
Considerations of this kind were also apparent in the NAACP's reaction to proposals to legitimize the formal teaching of 'Black English' in ghetto schools. In April 1971 the editor of The Crisis denounced a grant of $\$ 65,000$ from the Ford Foundation to establish such a course at Brooklyn College on the grounds that ' this language is merely the English of the undereducated '. He argued that it was much more important to improve the standard of black children in basic English than to emphasize the significance of a 'provincial patois ' which would simply ' limit their opportunities in the world at large '. ${ }^{105}$ For the NAACP, the study of Black English represented a retreat into unreality which would deny black children access to the worlds of politics, science and technology, and at the same time perpetuate all the standard myths and stereotypes of black inferiority.

This critical attitude towards 'Black English' extended to the entire ghetto culture of which it was a part. Like the Muslims, the NAACP found little of value in the life-style of the ghetto streets, and it deplored attempts to romanticize this culture through the symbolism of 'Soul' and the medium of the cinema. The Hollywood branch of the NAACP dismissed as a form of cultural genocide the "so-called black movies that glorify black males as pimps, dope pushers, gangsters and super males with vast physical prowess but no cognitive skills '. ${ }^{106}$ The vitality and emotional richness of ghetto life could not be denied, but for the moderate integrationists of the NAACP the concept of Soul and the self-conscious symbols of the African heritage represented a racist type of escapism, a fantasy world suitable only for those who were incapable of confronting the harsh realities of life in the real world. From this perspective the cultural renaissance was irrelevant if not injurious to black needs. Black pride, like Black Power, would have to come from another source.

\section{$\mathrm{V}$}

The cultural renaissance which had been such a force in Afro-American life in the late 1960 s had not died by the middle of the following decade, but there were definite signs that it was ailing. Soul was not the much-publicized symbol of solidarity and pride that it had been several years earlier. Afros and dashikis were still much in evidence but less fashionable than previously. Swahili was no longer being touted as essential to the recovery of black identity. Black Studies was no longer the controversial issue it had been. The radicals of the Black Arts Movement had failed to mobilize the masses and some of them had transferred their energies to other causes.

Many different factors contributed to the declining influence of the cultural

105 Ibid., 78 (April-May 1971), 78.

106 Junius Griffin, 'Hollywood and the Black Community', The Crisis, 80 (May 1973), 17 r. 
renaissance. Among the most important was the mixed response which it evoked among America's black leadership. The unity which had prevailed during the heyday of the civil rights campaign in the early r 960 s had been destroyed by the advent of Black Power and replaced by a confusing diversity of styles and strategies. With a marked absence of unity on a national scale and with black leaders divided into moderates and militants, separatists and integrationists, it was inevitable that there would be many different responses to the cultural renaissance. The renaissance was a force which could not be denied, but its acceptance by certain powerful organizations was often minimal and their hostile reactions were bound to slow its progress. Moreover, despite the obvious element of bias involved, it is clear in retrospect that some of the criticisms levelled at the cultural renaissance were perceptive and valid.

The movement had more than its share of unnecessarily militant rhetoric and empty clichés, and the exploitation of African costumes, hairstyles and languages was both artificial and limited in value. In addition, the underlying realities of ghetto culture were often sordid and unsuitable for idealization or conversion into symbols of ethnic pride, and what was usable was too often exploited for commercial gain. ${ }^{107}$ This is not to deny the vitality and the unique ethnic qualities of ghetto culture, but simply to suggest its limitations. Soul, like the pseudo-African heritage, promoted racial solidarity and black pride, but it was in certain respects a palliative, a substitute for a more significant cultural or political experience. Being 'Black and Beaútiful' could become an end in itself rather than a first step towards a more meaningful liberation, and an improved self-image did not alter the realities of ghetto poverty and unemployment. By the early 1970s the limitations of the Black Arts Movement were also apparent. Despite all the intentions of its creators the movement smacked of cultural élitism and never reached a really large audience in the black community. ${ }^{108}$

The community's involvement in the cultural renaissance was further weakened by changing political and economic circumstances. The increasing unfashionableness of Blacks and their problems, in politics and in the media, made it easy for the Nixon administration to adopt a laissez-faire attitude in such areas as civil rights enforcement and anti-poverty spending. Vernon Jordan, executive director of the National Urban League, stated in 1973: 'There is persuasive evidence that the Second Reconstruction is coming to an end.' ${ }^{109}$ The increasing level of economic recession also played an

107 Harold Cruse, The Crisis of the Negro Intellectual (New York, 1967), pp. 98-9.

108 According to one critic the Black Theatre, in particular, had failed to shake off its image

as 'an artifact of middle class snobbishness'. Richard Wesley, 'Toward a Viable Black

Film Industry ', Black World, 22 (July 1973), 24.

109 Cited in Peter Goldman, 'Black America Now', Newsweek, $x_{9}$ February 1973. 
important role by raising the rate of black unemployment and with it the associated problems of ghetto poverty and crime. The depression of the 1930s had brought the Harlem Renaissance to an abrupt end, and the realization that cultural concerns were less important than unpleasant economic and social realities contributed to the decline of its 1960 s counterpart.

The decline of the cultural renaissance is perhaps most obvious in the extent to which politics has replaced culture as a central consideration in the black community. The failures of government to deal with black problems, the explosion of black voter registration following the 1965 Voting Rights Act, and the existence of black majorities in some Southern counties and a growing number of Northern cities, have all encouraged this trend. Throughout the spectrum of black organizations, emphasis had shifted by $1972^{2-3}$ from raising the level of black consciousness to raising the level of political awareness.

This change of emphasis was apparent in the activities of organizations as different as the SCLC, the Urban League and especially the Black Panthers who abandoned their revolutionary rhetoric and their guns and sought a new relationship with the black masses through voter registration drives and local politics. ${ }^{110}$ An even more striking example of the new trend and, in particular, of the tendency to seek political rather than cultural solutions to black problems is provided by the activities, during the early 1970s, of LeRoi Jones (by this time known as Imamu Amiri Baraka). In 1970 Jones played an important role in the election of Kenneth Gibson as Mayor of Newark, and in subsequent years he was a leading figure in meetings of The Congress of African Peoples and the National Black Political Convention, both of which aimed to unite and politicize a broad spectrum of the black community. During these years Jones frequently stressed the importance of promoting community participation in local politics and he argued that it was the right kind of political party which could best give black people 'identity, purpose and direction '. ${ }^{111}$ Without necessarily abandoning all the premises of cultural nationalism LeRoi Jones had clearly modified both his rhetoric and his approach to the liberation of the black community.

Whether this developing interest in politics will provide more effective and more durable solutions to black problems is far from certain. Black political

110 The change in Black Panther policies and the progress of Bobby Seale's campaign for the Oakland mayoralty election are discussed in the New York Times, 20 August 1972, 1, p. 59; 8 April 1973, p. 38; and 20 May 1973, Iv, p. 8. For SCLC and Urban League activities see ibid., 7 January 1972, p. 9, and the League's National Progress Report for 1972.

111 New York Times, ix September 1971, p. 54. For Jones's activities during this period see also ibid., 5 September I970, p. 6; I I March 1972, p. I2; and Imamu Amiri Baraka (LeRoi Jones), 'Gary and Miami - Before and After', Black World, 21 (October 1972). 
power has grown rapidly since the passage of the Voting Rights Act. Where there were fewer than roo elected office holders before 1965 , the number stood at over 2,60o by 1973, according to the Joint Center for Political Studies. ${ }^{12}$ However, this still represents less than I per cent of the nation's elective jobs, and any radical increase in this figure will be limited by the fact that blacks constitute no more than II per cent of the total American population. Moreover, there is every likelihood that what might be described as the political renaissance will be undermined by problems similar to those which faced its cultural predecessor. In the past, the majority of ghetto Blacks have shown little interest in organized politics and the exhortations of the politicians may prove to be as ineffective as those of the cultural nationalists. Disunity within the Black community is another shared problem. The ideologies and aims of the various black organizations are as different in political as in cultural matters. The danger was already apparent in 1972 when the NAACP withdrew from involvement with the National Black Political Convention because it disagreed with parts of the agenda drawn up by that body. ${ }^{133}$ The Convention's theme of unity without uniformity was easier to state than to implement.

In discussing the growing black interest in politics it would be wrong to imply that the cultural renaissance is dead or that it accomplished nothing. A body of literature and music survives, not all of it spoiled by self-indulgence and the demands of ideology, some of it remarkable by any standards. Cultural workshops are still operating and Black Studies programmes are running successfully in many universities. The exploitation of 'Soul' and the 'African heritage' may have been artificial and commercial, but taken in conjunction with these other areas of activity it contributed to a surge of ethnic pride and an unprecedented level of black awareness. In 1972 a team of American psychologists conducted experiments which indicated clearly that both lower and middle-class black children had developed a much higher self-esteem than had been evident ten years earlier. There was no longer the same tendency for these children to identify with white models and the explanation of the psychologists was that 'black children have come to appreciate their uniqueness, beauty and special value... personal pride is essentially the expression of group pride ' ${ }^{114}$ In a 1973 interview Jesse Jackson also paid tribute to the influence of the cultural renaissance and at the same time described it as a necessary prerequisite for political, economic, or any

112 Cited in the New York Times, 29 August 1973, p. 16.

113 This disagreement is mentioned in the New York Times, ro March 1972, p. 20; 13 March

1972, I; 14 March 1972, p. 3r. For the final withdrawal of the NAACP, see the issue of 17

May 1972, p. 9.

114 Ibid., 9 July r972, p. 21 . 
other kind of solution to black problems. 'We have more ethnic consciousness now', he stated; 'We are less likely to be put back into white slavery. We are better equipped intellectually, emotionally and technically to protect ourselves. We finally had to come to that independence to get to the next step.' ${ }^{115}$ The priorities of this next stage in the black struggle for equality have altered but the cultural renaissance is not dead. It has simply modified its rhetoric, altered its style, and begun to express itself in other ways 